\title{
Metal release from serpentine soils in Sri Lanka
}

\author{
Meththika Vithanage • Anushka Upamali Rajapaksha • \\ Christopher Oze • Nishanta Rajakaruna • \\ C. B. Dissanayake
}

\begin{abstract}
Ultramafic rocks and their related soils (i.e., serpentine soils) are non-anthropogenic sources of metal contamination. Elevated concentrations of metals released from these soils into the surrounding areas and groundwater have ecological-, agricultural-, and human health-related consequences. Here we report the geochemistry of four different serpentine soil localities in Sri Lanka by coupling interpretations garnered from physicochemical properties and chemical extractions. Both $\mathrm{Ni}$ and $\mathrm{Mn}$ demonstrate appreciable release in water from the Ussangoda soils compared to the other three localities, with $\mathrm{Ni}$ and $\mathrm{Mn}$ metal release increasing with increasing ionic strengths at all sites. Sequential extraction experiments, utilized to identify "elemental pools," indicate that $\mathrm{Mn}$ is mainly associated with oxides/(oxy)hydroxides, whereas $\mathrm{Ni}$ and $\mathrm{Cr}$ are bound in silicates and spinels. Nickel was the most bioavailable metal compared to $\mathrm{Mn}$ and $\mathrm{Cr}$ in all four soils, with the highest value observed in the Ussangoda soil at $168 \pm$ $6.40 \mathrm{mg} \mathrm{kg}{ }^{-1}$ via the $0.01-\mathrm{M} \mathrm{CaCl}_{2}$ extraction.
\end{abstract}

M. Vithanage $(\bowtie) \cdot$ A. U. Rajapaksha $\cdot$ C. B. Dissanayake Chemical and Environmental Systems Modeling Research Group, Institute of Fundamental Studies,

Kandy, Sri Lanka

e-mail: meththikavithanage@gmail.com

C. Oze

Department of Geological Sciences, University of Canterbury, Private Bag 4800, Christchurch, New Zealand

N. Rajakaruna

College of the Atlantic,

105 Eden Street, Bar Harbor, ME 04609, USA
Although $\mathrm{Mn}$ is dominantly bound in oxides/ (oxy)hydroxides, Mn is widely dispersed with concentrations reaching as high as $391 \mathrm{mg} \mathrm{kg}^{-1}$ (Yudhaganawa) in the organic fraction and $49 \mathrm{mg} \mathrm{kg}^{-1}$ (Ussangoda) in the exchangeable fraction. Despite $\mathrm{Cr}$ being primarily retained in the residual fraction, the second largest pool of $\mathrm{Cr}$ was in the organic matter fraction (693 $\mathrm{mg} \mathrm{kg}^{-1}$ in the Yudhaganawa soil). Overall, our results support that serpentine soils in Sri Lanka offer a highly labile source of metals to the critical zone.

Keywords Chemical extractions · Natural attenuation . Labile toxic metals $\cdot$ Serpentine geoecology $\cdot$ EPMA

\section{Introduction}

Metamorphosed ultramafic rocks are distributed worldwide and are commonly associated with ophiolite complexes (Coleman and Jove 1992; Coleman 1977; Harrison and Rajakaruna 2011). Serpentinites, compositionally ultramafic rocks, form through the subduction and alteration of peridotite and pyroxenite along convergent plate margins (Coleman and Jove 1992; Oze et al. 2004a; O'Hanley 1996). Serpentinites and related serpentine soils comprise less than $1 \%$ of the Earth's total exposed surface; however, they contribute greatly to generating and maintaining biodiversity (Harrison and Rajakaruna 2011). Initially, the process of serpentinization occurs as peridotite and pyroxenite rocks [i.e., rocks dominantly composed of Fe- and 
$\mathrm{Mg}$-rich silicate minerals such as olivine $\left(\left(\mathrm{Mg}, \mathrm{Fe}^{2+}\right)_{2}\right.$ $\left.\left[\mathrm{Si}_{2} \mathrm{O}_{4}\right]\right)$ and pyroxene $\left.\left(\mathrm{XY}(\mathrm{Si}, \mathrm{Al})_{2} \mathrm{O}\right)\right]$ are altered by hydrothermal fluids and incorporated into subductionrelated mélange (Gough et al. 1989; O’Hanley 1996; Oze et al. 2004a; Coleman 1977). Hydration of pyroxene and olivine forms the serpentine group of minerals (i.e., lizardite, chrysotile, and antigorite) from which these rocks and soils derive their names.

Serpentinite rocks are enriched with $\mathrm{Cr}, \mathrm{Co}$, and $\mathrm{Ni}$ and have the potential to adversely impact environmental and human health once metal ions are mobilized into soil, water, and dust by weathering (Alves et al. 2011; Rajapaksha et al. 2012; Cheng et al. 2011). Nickel and $\mathrm{Cr}(\mathrm{III})$ can substitute for $\mathrm{Mg}$ or Fe in octahedral sites in olivine and pyroxene in peridotites and in the serpentine group of minerals (Oze et al. 2004b). Since pyroxene and olivine in peridotite weather more quickly than serpentine minerals (Alexander 2004), the lability of $\mathrm{Ni}$ and $\mathrm{Cr}$ in rocks and soils derived from ultramafic sources may be a function of the degree of serpentinization. Chromium is mostly found in spinel minerals as chromian magnetite, chromite, and other mixed-composition spinels containing $\mathrm{Al}, \mathrm{Cr}, \mathrm{Mg}$, and Fe (Oze et al. 2004b).

Weathering and other pedogenic processes form serpentine soils, a generic term used to describe any soil derived from serpentinite and other ultramafic rocks regardless of its physical or chemical properties (Oze 2003). Serpentine soils are generally characterized by: (1) low concentrations of plant nutrients such as N, P, and K; (2) high concentrations of biologically toxic elements including $\mathrm{Ni}, \mathrm{Co}$, and $\mathrm{Cr}$; (3) $\mathrm{Ca} / \mathrm{Mg}$ quotients $\ll 1$; (4) low water holding capacity due to the rocky, shallow, and often exposed nature of the outcrops; and (5) distinct biota, particularly plants, often endemic to such soils (Brooks 1987; Harris and Rajakaruna 2009; Oze et al. 2008).

Ultramafic rocks and soils are widely but patchily distributed on Earth; they are found on every continent and in every major biome (Harrison and Kruckeberg 2008). Serpentine outcrops on some continents (Australia, Europe, North America) are relatively wellstudied, but those in many other areas (Asia, Africa, Central and South America) are relatively unexplored (Boyd et al. 2009). Studies to date show that in many areas of the world serpentine outcrops harbor vegetation distinct from that of adjacent areas, often characterized by high endemism and rarity (Brooks 1987; Harrison and Rajakaruna 2011; Rajakaruna et al. 2009).

Geochemical studies on serpentinites and serpentine soils have mostly focused on $\mathrm{Cr}$ (Armienta et al. 1996; Becquer et al. 2003; Camachoa and Armientac 2000; Cheng et al. 2011; Gough et al. 1989; Oze et al. 2004a, b). Nickel has also received some attention (Amir and Pineau 2003; Alves et al. 2011; Cheng et al. 2011; Proctor and Baker 1994; Rajapaksha et al. 2012). However, not many studies have focused on serpentines in tropical regions where weathering rates are typically high due to high annual rainfall and temperature. In Sri Lanka, a continental island in the equatorial belt, several serpentine outcrops are present (Dissanayaka 1982). The serpentine outcrops in Sri Lanka have received some attention by botanists (Rajakaruna and Bohm 2002; Rajakaruna et al. 2002), and the studies to date have revealed several potential $\mathrm{Ni}$ hyperaccumulators, species accumulating over 1,000 $\mu \mathrm{g} \mathrm{Ni} / \mathrm{g}$ dry leaf tissue (Van der Ent et al. 2013), from the Ussangoda site (Rajakaruna and Baker 2004; Senevirathne et al. 2000; Weerasinghe and Iqbal 2011).

Despite a handful of published research on the geochemistry (Dissanayaka 1982; Rajapaksha et al. 2012) and plant ecology (Brooks 1987; Rajakaruna and Baker 2004; Rajakaruna and Bohm 2002; Rajakaruna et al. 2002; Senevirathne et al. 2000; Weerasinghe and Iqbal 2011) of mostly the Ussangoda site, there is minimal research to date on the geochemistry and associated geoecology of Sri Lanka's serpentine soils. This is rather surprising given that Sri Lanka, a biodiversity hotspot (Myers et al. 2000), is home to many endemic species and these under-explored outcrops could potentially harbor "new" species or ecotypes endemic to the substrate (Rajakaruna and Baker 2004). In this study, we examine if metal accessibility and release is comparable among the four known outcrops in Sri Lanka and assess the potential release of heavy metals, including $\mathrm{Cr}, \mathrm{Mn}$, and $\mathrm{Ni}$, from the serpentines soils to the surrounding environment.

Geological setting and description of the study sites

Geologically, $90 \%$ of Sri Lanka consists of rocks of Precambrian age (Cooray 1984). The other $10 \%$ consists mainly of Miocene Limestone, restricted to northwestern Sri Lanka (Fig. 1). Additionally, there are a few shale beds of the Jurassic period around the areas of 


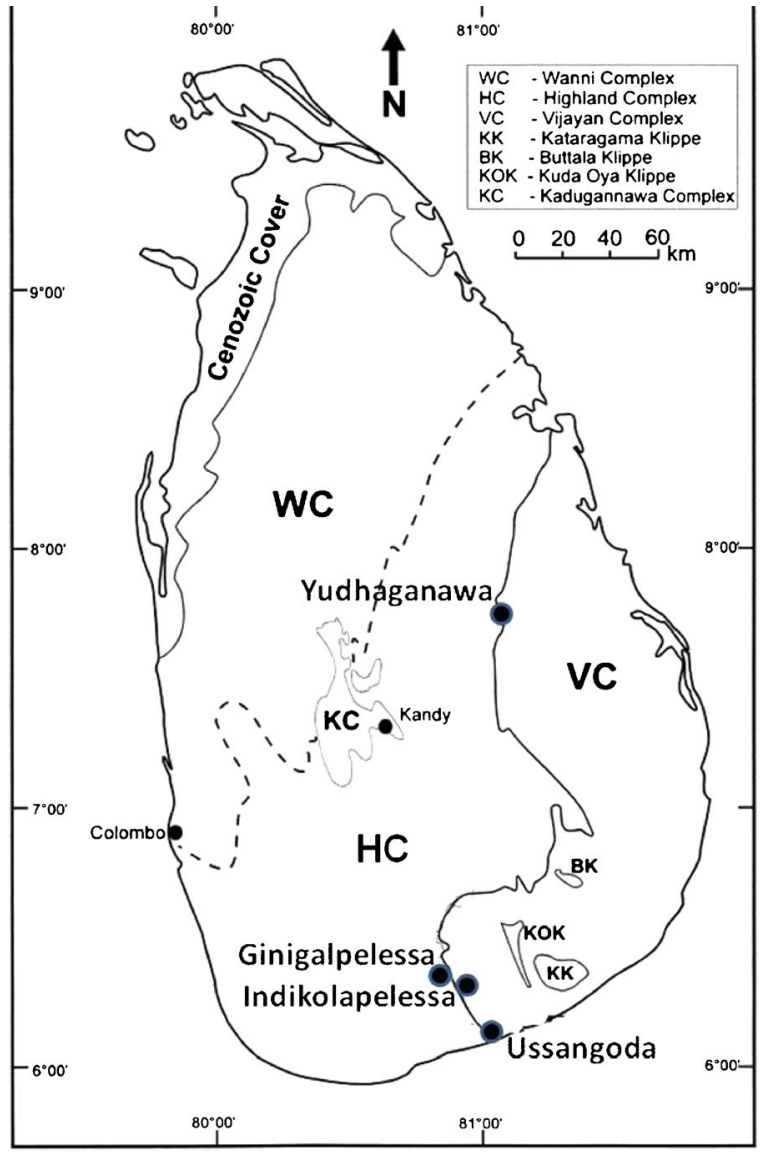

Fig. 1 The geological map of Sri Lanka indicating the four serpentine outcrops along $\mathrm{VC}-\mathrm{HC}$ boundary (the solid and dotted lines represent $\mathrm{HC}-\mathrm{VC}$ and $\mathrm{HC}-\mathrm{WC}$ boundaries, respectively)

Thabbowa and Andigama in the northwestern and western provinces of the island, respectively. Based on the rock types, their origin, and their metamorphic condition, Sri Lanka's metamorphic terrain is divided into four main geological units (The Highland Complex, $\mathrm{HC}$; the Vijayan Complex, VC; the Wanni Complex, WC) and one subordinate unit (Kadugannawa Complex, KC; Fig. 1). The central highlands, extending toward the northeast up along the east coast and to the southwest up along the southwestern coast, are included as part of $\mathrm{HC}$. The rocks in $\mathrm{HC}$ originated under very high temperature $\left(700-800{ }^{\circ} \mathrm{C}\right)$ and pressure $(5-10 \mathrm{~Kb})$ (Cooray 1984).

The VC occupies the eastern section of $\mathrm{HC}$, and $\mathrm{WC}$ is found on the western portion of HC up to the Miocene Limestone (Cenozoic cover in Fig. 1). The geological boundary between $\mathrm{HC}$ and $\mathrm{VC}$ has been considered as a mini-plate boundary (Munasinghe and Dissanayake
1980) due to the mineralization that occurs along this boundary. However, there is no definite margin indicative of the plate boundary, only a widespread mineralized belt. The $\mathrm{KC}$ lies along the middle of $\mathrm{HC}-\mathrm{WC}$ boundary.

The serpentinite outcrops of Sri Lanka lie along the boundary of the HC and VC (Fig. 1). Of these, Indikolapelessa serpentinite deposit is the only deposit studied in detail for its petrology and geochemistry (Dissanayaka 1982). The extent of this deposit is recorded to be $\sim 7 \mathrm{~km}^{2}$ surrounded by charnockites, calcgneiss, migmatites, cordierite, and diopside bearing gneisses and calciphyres. Geophysical and bore logging explorations have revealed that the serpentinite bodies have a deep-seated origin. Nickel is a prominent feature of the Indikolapelessa deposit (0.05-2 \%), partly as an iron oxide phase, whereas $\mathrm{Cr}$ is reported in the range of 300-3,100 mg kg-1 (Dissanayaka 1982).

The Ussangoda serpentine outcrop is located in the southern coastal end of the HC-VC boundary (Fig. 1). The area of the outcrop is estimated as $3 \mathrm{~km}^{2}$, and the soil has been described as hematite rich with very finegrained clayey sand, giving a lateritic reddish hue (Rajakaruna and Bohm 2002). Previous geochemical studies at this site revealed soil $\mathrm{Ni}$ and $\mathrm{Cr}$ concentrations of 1,000 and $7,700 \mathrm{mg} \mathrm{kg}^{-1}$, respectively, compared to 2,100 and $10,000 \mathrm{mg} \mathrm{kg}^{-1} \mathrm{Ni}$ and $\mathrm{Cr}$, respectively, at the Ginigalpelessa outcrop (Ranasinghe 1987). The Ginigalpelessa outcrop is estimated to cover an area of $\sim 1 \mathrm{~km}^{2}$. Currently, no geochemical studies have been conducted at the Yudhaganawa serpentine deposit.

\section{Materials and methods}

Sample collection and preparation

The serpentine soils used for the study were collected from all four known serpentine outcrops in Sri Lanka: Ussangoda, Ginigalpelessa, Indikolapelessa, and Yudhaganawa (Figs. 1 and 2). Ten soil samples were obtained from each outcrop, all within comparable topographies. These soils are a direct weathering product of the rocks beneath (Dissanayake and Van Riel 1978). A composite sample for each was prepared by mixing the ten samples. Each soil sample was air-dried and mechanically sieved to obtain the $<2-\mathrm{mm}$ fraction for 

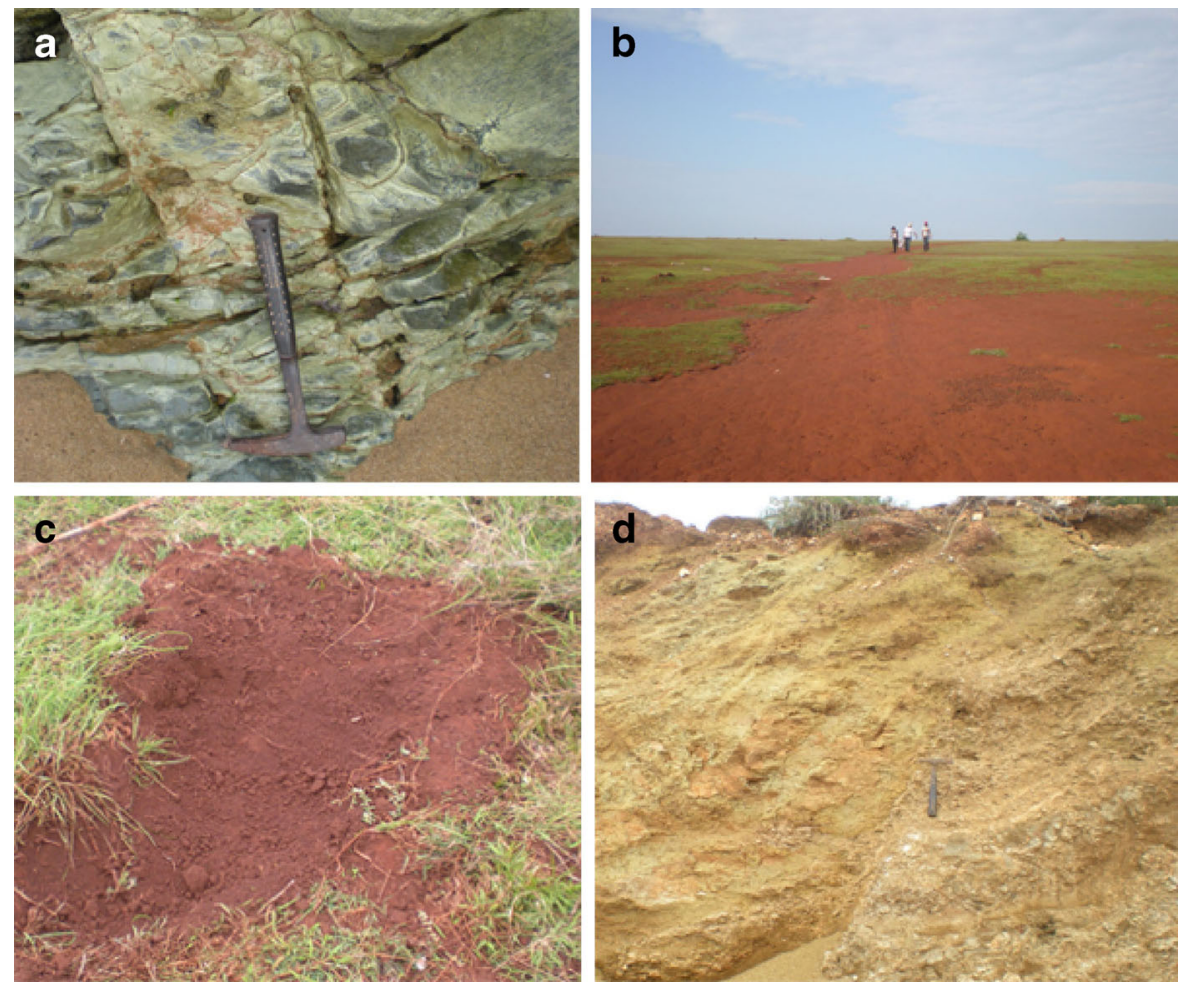

Fig. 2 Serpentinite soils of Sri Lanka: a serpentinite rock outcrop at Ussangoda, b serpentine soil at Ussangoda, c serpentine soil at Yudhaganawa, and $\mathbf{d}$ the soil profile at Indikolapelessa

geochemical investigations. Five replicate samples from each site were used for each chemical analysis.

Physicochemical characteristics of serpentine soils

All chemicals used were of analytical grade and purchased from Fluka (Switzerland) or Sigma (USA). All laboratory glassware and plastic ware were rinsed three times with double deionized water after being soaked in a $\mathrm{HNO}_{3}(10 \%, v / v)$ bath overnight. The parameters measured include $\mathrm{pH}$, electrical conductivity (EC), organic carbon, and elemental composition. The $\mathrm{pH}$ was determined using a 1:1 mixture of soil to deionized water. EC was determined from a $2 \mathrm{~mL}$ of soil solution extract.

For heavy metal analysis, all the extracts were acidified with $\mathrm{HNO}_{3}$ to prevent adsorption to the polyethylene of the storage vessel and prevent growth of bacteria. The acidified supernatant was collected in polyethylene bottles and stored at $4{ }^{\circ} \mathrm{C}$ until metal analysis. Three replicates were performed for each sample and each procedure, as three independent analyses. Blanks were measured in parallel for each batch of analysis.
Total metal concentrations in soils

Major and trace elements of the soils were analyzed via X-ray fluorescence (XRF) spectrometry using a PANalytical MagiX PRO spectrometer (Institute for Geography and Geology, University of Copenhagen). Trace elements in soils were extracted by completely dissolving the samples in a closed vessel device using temperature-controlled microwave heating system with a mixture of hot, concentrated $\mathrm{HNO}_{3}, \mathrm{HCl}$, and $\mathrm{HF}$ (Sun et al. 2001) (Milestone ETHOS PLUS Labstation with HRP-1000/10S High Pressure Segmented Rotar), and analyzed by atomic absorption spectrometry (AAS) (AAS-Model GBC AAS 933A). Triplicate analyses were conducted for each sampling site for total digestion; however, only one sample was conducted for XRF analysis. X-ray diffraction (XRD) was used to identify the minerals in soils. Serpentine soils $(63-105 \mu \mathrm{m})$ were evaluated via XRD using a Siemens D-5000 diffractometer operating at $40 \mathrm{kV}$ and $40 \mathrm{~mA}$ (using $\mathrm{CuK} \alpha$ radiation). X-ray diffraction patterns were collected between 2 values of 2.0-80.0 and at a scan speed of $1.0^{\circ} \mathrm{min}^{-1}$. The electron probe microanalysis (EPMA) of the 
serpentine soil samples was carried out to identify the $\mathrm{Ni}-, \mathrm{Mn}-$, and Cr-bound phases. Elemental mapping for metals was carried at Seoul National University.

\section{Surface titrations}

The zero point of charge $\left(\mathrm{pH}_{\mathrm{ZPC}}\right)$ of the serpentine sediments was determined by conventional potentiometric titration methods (Langmuir 1997). A 2-g L $\mathrm{L}^{-1}$ serpentine sediment (63-105 $\mu \mathrm{m}$ fractions) suspension was equilibrated for $24 \mathrm{~h}$. Three titration experiments were performed utilizing $0.1,0.01$, and $0.001 \mathrm{M}$ $\mathrm{NaNO}_{3}$. The initial $\mathrm{pH}$ of serpentine soil suspension was $\sim 5.5$, and it was lowered to $\sim 4$ with $0.10 \mathrm{M}$ $\mathrm{HNO}_{3}$ prior to titrations. At each titration point, the $\mathrm{pH}$ value and the titrant volume (Model Orion 960 auto chemistry analyzer) were recorded. The surface charge $\left(\sigma_{\mathrm{H}}\right)$ was calculated using the Eq. 1 below (Stumm and Morgan 1996).

$\sigma_{\mathrm{H}}=\frac{\left(C_{\mathrm{A}}-C_{\mathrm{B}}+\left[\mathrm{OH}^{-}\right]-\left[\mathrm{H}^{+}\right]\right) F}{a S}$

where $\sigma_{\mathrm{H}}$ is the surface charge (in coulomb per square meter), $C_{\mathrm{A}}$ is the added acid concentration, $C_{\mathrm{B}}$ is the added base concentration, $\left[\mathrm{OH}^{-}\right]$is the hydroxyl ion concentration, $\left[\mathrm{H}^{+}\right]$is the proton concentration, $a$ is equilibrium $\mathrm{OH}^{-}$and $\mathrm{H}^{+}$concentrations for a given quantity of solid used (in grams per liter), $F$ is the Faraday constant $\left(96,500 \mathrm{C} \mathrm{mol}^{-1}\right)$, and $S$ represents the surface area determined by $\mathrm{N}_{2}$ BET isotherm analysis.

\section{Single extractions}

\section{Ammonium acetate extraction}

The readily exchangeable and water-soluble cations (K, $\mathrm{Ca}, \mathrm{Mg}$, and $\mathrm{Na}$ ) were determined by using ammonium acetate at $\mathrm{pH}$ 7.0. The procedure involved weighing $2 \mathrm{~g}$ of soil and adding $25 \mathrm{~mL}$ of ammonium acetate $(20 \mathrm{M}$ $\mathrm{NH}_{4} \mathrm{OAc}$ ) followed by mixing on an orbital shaker for 30 min (Castilho and Rix 1993). The solution was filtered using a $0.45-\mu \mathrm{m}$ quantitative filter paper. Potassium, $\mathrm{Ca}, \mathrm{Mg}$, and $\mathrm{Na}$ concentrations were analyzed using an atomic absorption spectrophotometer (GBC AAS 933A).

\section{Diethylene triamine pentaacetic acid and $\mathrm{CaCl}_{2}$ extractions}

The diethylene triamine pentaacetic acid (DTPA) and $\mathrm{CaCl}_{2}$ extraction methods provide a proxy for evaluating plant bioavailability of metals in soils and soil solutions (Kashem et al. 2007; Peijnenburg et al. 2007). Bioavailability of metals in the serpentine soil samples was quantified by the DTPA soil test (Lindsay and Norvell 1978). Approximately $20 \mathrm{~mL}$ of a $0.005-\mathrm{M}$ DTPA, $0.01 \mathrm{M} \mathrm{CaCl}_{2}$, and $0.1 \mathrm{M}$ triethanolamine buffered solution were added to $10 \mathrm{~g}$ of air-dried soil for $2 \mathrm{~h}$. The filtrate was analyzed for $\mathrm{Cr}, \mathrm{Mn}, \mathrm{Fe}, \mathrm{Ni}, \mathrm{Co}, \mathrm{Cu}$, and $\mathrm{Zn}$ by AAS.

Additionally, the 0.01- $\mathrm{M} \mathrm{CaCl}_{2}$ method (Houba et al. 1996) was also employed to reassess the bioavailable fraction of metals. One gram of soil was extracted with $10 \mathrm{~mL}$ of $0.01 \mathrm{M} \mathrm{CaCl}_{2}$ by stirring the solid solution for $2 \mathrm{~h}$ and centrifuging and filtering through a $0.45-\mu \mathrm{m}$ pore size membrane. The supernatant was used to analyze $\mathrm{Ni}, \mathrm{Mn}$, and $\mathrm{Cr}$ via $\mathrm{AAS}$.

Sequential extractions to determine $\mathrm{Cr}, \mathrm{Mn}$, and $\mathrm{Ni}$ mineral phases

Sequential extractions involve the selective extraction of trace metals from operationally defined sediment solid fractions (Tessier et al. 1979; Gleyzes et al. 2002), providing detailed information about the different availabilities of heavy metals among distinct geochemical phases. Ideally, the reagents are chosen to selectively attack a specific soil compartment with minimal dissolution of nontargeted phases. Although the separation of various chemical forms of heavy metals is difficult, sequential extraction methods provide a favorable approach (Tessier et al. 1979). The dominant mineral phase may not contribute to the highest integration with metal ions due to the low reactivity and surface area compared to the other highly reactive mineral phases. Hence, chemical extractions may provide a final "snap shot" of the dynamic processes occurring in the soil.

Sequential extraction experiments were performed on the serpentine soils following the methods of Tessier et al. (1979) and Armienta et al. (1996). A mass of $1 \mathrm{~g}$ of serpentine soil (dry weight) was used for the initial extraction. A total of five replicate sequential extraction analyses were completed on the sediment. Nickel, $\mathrm{Cr}$, and $\mathrm{Mn}$ concentrations were measured in the effluent after each extraction using AAS. In the 
Table 1 Chemical properties of soils

\begin{tabular}{lllllr}
\hline Locations & $\mathrm{pH}$ & $\mathrm{EC}\left(\mathrm{dS} \mathrm{m}^{-1}\right)$ & $\begin{array}{l}\text { Organic } \\
\text { matter }(\%)\end{array}$ & $\begin{array}{l}\text { Cation exchange } \\
\text { capacity }(\mathrm{C} \mathrm{mol} / \mathrm{kg})\end{array}$ & $\mathrm{pH}$ ZPC \\
\hline Ussangoda & $6.68 \pm 0.08$ & $0.13 \pm 0.011$ & $1.92 \pm 0.02$ & $101.80 \pm 0.05$ & 8.57 \\
Yudhaganawa & $6.26 \pm 0.03$ & $0.03 \pm 0.015$ & $2.58 \pm 0.11$ & $86.15 \pm 0.02$ & 8.90 \\
Ginigalpelessa & $6.88 \pm 0.04$ & $0.05 \pm 0.010$ & $1.26 \pm 0.08$ & $76.96 \pm 0.07$ & 8.30 \\
Indikolapelessa & $7.69 \pm 0.01$ & $0.12 \pm 0.018$ & $1.09 \pm 0.01$ & $73.98 \pm 0.03$ & 8.01 \\
\hline
\end{tabular}

of one composite sample

following is a list of the extraction procedures performed on the sediment:

(a) Exchangeable: Sediment was reacted at room temperature for $1 \mathrm{~h}$ with $20 \mathrm{~mL}$ of magnesium chloride solution (1 $\mathrm{M} \mathrm{MgCl}_{2}, \mathrm{pH}$ 7.0) with continuous agitation.

(b) Bound to carbonates. Residue from (a) was leached at room temperature for $2 \mathrm{~h}$ with $20 \mathrm{~mL}$ of $1 \mathrm{M}$ sodium acetate $(\mathrm{NaOAc})$ adjusted to $\mathrm{pH} 5.0$ with acetic acid (HOAc) and with continuous agitation.

(c) Bound to $\mathrm{Fe}-\mathrm{Mn}$ oxide: Residue from (b) was treated with $20 \mathrm{~mL}$ of $0.04 \mathrm{M}$ hydroxylamine hydrochloride $\left(\mathrm{NH}_{2} \mathrm{OH}-\mathrm{HCl}\right)$ in $25 \%(v / v)$ HOAc heated at $90{ }^{\circ} \mathrm{C}$ with slow continuous agitation for $2 \mathrm{~h}$.

(d) Bound to organic matter: Residue from (c) was treated with $3 \mathrm{~mL}$ of $0.02 \mathrm{M} \mathrm{HNO}_{3}$ and $5 \mathrm{~mL}$ of $30 \% \mathrm{H}_{2} \mathrm{O}_{2}$ adjusted to $\mathrm{pH} 2$ with $\mathrm{HNO}_{3}$, heated to $85{ }^{\circ} \mathrm{C}$ for $2 \mathrm{~h}$ with occasional agitation. A $3-\mathrm{mL}$ aliquot of $30 \% \mathrm{H}_{2} \mathrm{O}_{2}\left(\mathrm{pH} 2\right.$ with $\mathrm{HNO}_{3}$ ) was added, and the sample was heated again to $85{ }^{\circ} \mathrm{C}$ for $3 \mathrm{~h}$ with intermittent agitation. After cooling,

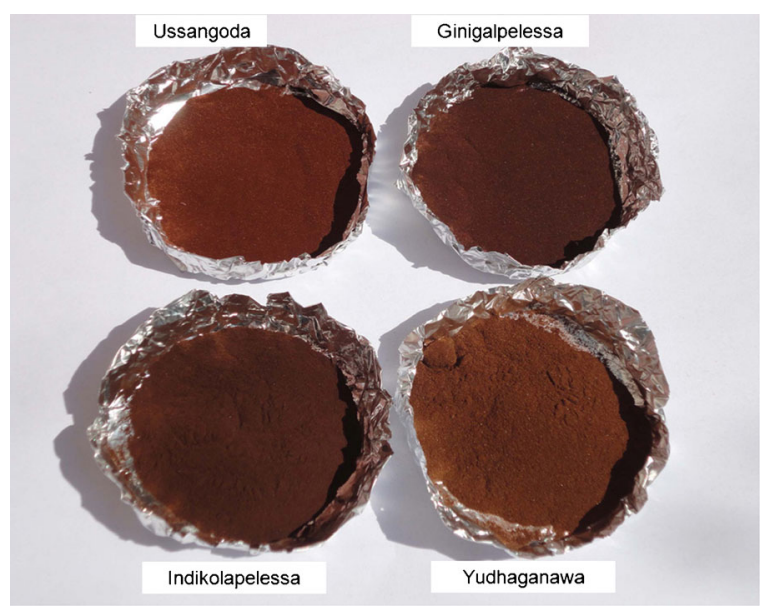

Fig. 3 The differences in soil color for soil samples from the four sites
$5 \mathrm{~mL}$ of $3.2 \mathrm{M} \mathrm{NH}_{4} \mathrm{OAc}$ in $20 \%(v / v) \mathrm{HNO}_{3}$ was added, and the sample was diluted to $20 \mathrm{~mL}$ and agitated continuously.

(e) Residual: Residue from (d) was treated with a mixture of $10 \mathrm{~mL}$ concentrated $\mathrm{HF}$ and $2 \mathrm{~mL}$ concentrated $\mathrm{HClO}_{4}$ and heated to near dryness. It was then treated with $1 \mathrm{~mL} \mathrm{HClO}_{4}+10 \mathrm{~mL} \mathrm{HF}$ and heated again to near dryness; $1 \mathrm{~mL} \mathrm{HClO}_{4}$ was added, heated until the appearance of white fumes, and finally dissolved with $12 \mathrm{~N} \mathrm{HC1}$ and diluted to $25 \mathrm{~mL}$ with deionized water.

Between each successive extraction listed above [(b) to (e)], the sample was centrifuged at 3,500 rpm for $15 \mathrm{~min}$. Additionally, the supernatant was filtered using $0.45 \mu \mathrm{m}$ filter paper prior to AAS analysis.

Effect of ionic strength and water for metal ion release

Metal release batch experiments were carried out using distilled water to observe $\mathrm{Ni}, \mathrm{Cr}$, and $\mathrm{Mn}$ release from the sediment with respect to time. This experiment was performed to investigate the dependence of toxic metal release due to the variation in ionic strength. Since one of the serpentine sites is located along the coast (Ussangoda), sea spray may contain salts which can increase the ionic strength of the soil solution. Thus, the experiment was conducted to characterize any variation of metal release due to changes in ionic strength, resulting from salt spray. A mass of $5 \mathrm{~g}$ of solid sample per L of water $\left(5 \mathrm{~g} \mathrm{~L}^{-1}\right.$ sediment suspension) was initially used where subsamples of $25 \mathrm{~mL}$ suspension were taken from the batch experiments over 20 days. Nickel, Cr, and $\mathrm{Mn}$ release with different ionic strengths was analyzed using $0.1,0.01$, and $0.001 \mathrm{M} \mathrm{NaNO}_{3}$ solutions by changing the solution $\mathrm{pH}$ (4-9). A 5$\mathrm{g} \mathrm{L}^{-1}$ sediment suspension was prepared and adjusted to $\mathrm{pH} \sim 4$ in desired ionic strengths $(0.1,0.01$, and 0.001$)$ by $5 \mathrm{M} \mathrm{NaNO}_{3}$. The system $\mathrm{pH}$ was incrementally increased at $\sim 1.0 \mathrm{pH}$ intervals up to $\sim 9$. At each point, 


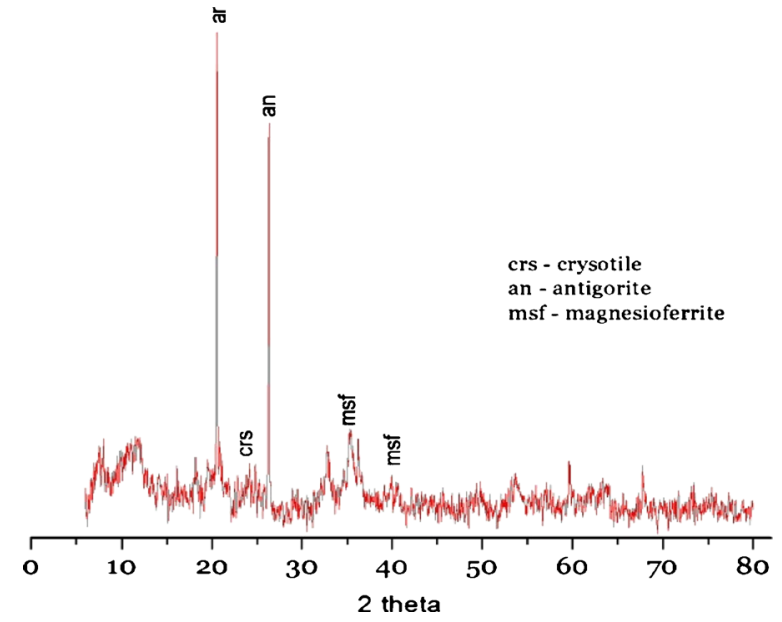

Fig. 4 X-ray diffractogram of Ussangoda serpentine soil

a 25-mL sample portion was transferred to a capped polypropylene tube. These tubes were equilibrated for $24 \mathrm{~h}$ at $75 \mathrm{rpm}$ (EYELA B603 shaker), and the $\mathrm{pH}$ of the suspension was re-measured and recorded. Membrane-filtered supernatant was used for $\mathrm{Ni}, \mathrm{Cr}$, and Mn analysis via AAS.

Inorganic and organic acid extractions

Organic and inorganic acids can be found in the environment due to plant and microbial activity in the rhizosphere and via dissolved ions in rainwater. These acids can play a role in metal release due to the change of $\mathrm{pH}$ of the soil solution. Therefore, three inorganic (sulfuric, nitric, hydrochloric) and three organic (citric, acetic, oxalic) acids of different concentrations ( 0.05 , $0.1,0.5,1.0,5.0$, and $10 \mathrm{mM}$ ) were used to evaluate $\mathrm{Cr}$, $\mathrm{Ni}$, and $\mathrm{Mn}$ release from the sediment. Approximately $1 \mathrm{~mL}$ (15-20 drops) of chloroform was added per liter of all organic acid solutions to prevent microbial breakdown of the organic acids. Half a gram of sediment was placed in polypropylene tubes, and $25 \mathrm{~mL}$ of each acid was added. The tubes were equilibrated for $24 \mathrm{~h}$ at room temperature and agitated at $75 \mathrm{rpm}$ (Model EYELA B603 shaker). The supernatant was transferred by membrane filtration $(0.45 \mu \mathrm{m})$ after centrifugation, and the solutions were analyzed for $\mathrm{Mn}$ and $\mathrm{Ni}$ using the flame method of AAS.

\section{Results and discussion}

Serpentine soil chemistry

Chemical properties ( $\mathrm{pH}$, electrical conductivity, organic matter, cation exchange capacity) for four soil samples from Ussangoda, Yudhaganawa, Ginigalpelessa, and Indikolapelessa are listed in Table 1 . The $\mathrm{pH}$ values

Table 2 Elemental compositions and chemistry of serpentine soils at each location

\begin{tabular}{|c|c|c|c|c|c|c|c|c|c|}
\hline \multicolumn{10}{|l|}{ Major elements } \\
\hline Sample (\%) & $\mathrm{SiO}_{2}$ & $\mathrm{TiO}_{2}$ & $\mathrm{Al}_{2} \mathrm{O}_{3}$ & $\mathrm{Fe}_{2} \mathrm{O}_{3}$ & $\mathrm{MnO}$ & $\mathrm{MgO}$ & $\mathrm{Na}_{2} \mathrm{O}$ & $\mathrm{K}_{2} \mathrm{O}$ & $\mathrm{P}_{2} \mathrm{O}_{5}$ \\
\hline Ussangoda & 41.00 & 1.43 & 12.20 & 38.30 & 0.33 & 0.94 & 0.04 & 0.45 & 0.17 \\
\hline Yudhaganawa & 33.20 & 1.20 & 7.29 & 32.2 & 0.48 & 2.98 & 0.16 & 0.66 & 0.11 \\
\hline Ginigalpelessa & 39.10 & 0.49 & 7.92 & 23.30 & 0.46 & 2.98 & 0.12 & 0.27 & 0.10 \\
\hline Indikolapelessa & 45.3 & 1.55 & 12.7 & 17.50 & 0.29 & 4.22 & 0.43 & 0.76 & 0.11 \\
\hline \multicolumn{10}{|l|}{ Minor elements } \\
\hline Sample $\left(\mathrm{mg} \mathrm{kg}^{-1}\right)$ & $\mathrm{Ni}$ & $\mathrm{Mn}$ & $\mathrm{Cr}$ & $\mathrm{Pb}$ & V & $\mathrm{Zn}$ & Co & $\mathrm{Sr}$ & $\mathrm{Rb}$ \\
\hline Ussangoda & 6,459 & 1,120 & 11,031 & 7 & 137 & 156 & 111 & 29 & 36 \\
\hline Yudhaganawa & 6,130 & 2,263 & $>10,000$ & 111 & $<5$ & 302 & 446 & 111 & 27 \\
\hline Ginigalpelessa & 6,080 & 2,224 & $>10,000$ & 6 & $<5$ & 270 & 402 & 78 & 41 \\
\hline Indikolapelessa & 4,932 & 1,342 & 8,260 & 34 & $<5$ & 126 & 198 & 313 & 13 \\
\hline \multicolumn{10}{|c|}{ Total metal digestion results $\left(\mathrm{mg} \mathrm{kg}^{-1}\right)$} \\
\hline Location & $\mathrm{Ni}$ & $\mathrm{Mn}$ & $\mathrm{Cr}$ & Co & $\mathrm{Cu}$ & $\mathrm{Zn}$ & & & \\
\hline Ussangoda & 6,776 & 1,117 & 10,707 & 157 & 30 & 173 & & & \\
\hline Yudhaganawa & 6,567 & 2,609 & 14,880 & 555 & 14 & 307 & & & \\
\hline Ginigalpelessa & 5,945 & 2,543 & 9,948 & 219 & 15 & 182 & & & \\
\hline Indikolapelessa & 4,705 & 1,349 & 6,737 & 241 & 24 & 108 & & & \\
\hline
\end{tabular}


of all soils are near neutral ( $\mathrm{pH}$ from 6.26 to 7.69 ). EC in the soils range from 33.50 to $129.90 \mu \mathrm{S} \mathrm{cm}^{-1}$, indicative of relatively few dissolved salts and/or major dissolved inorganic solutes. The highest $\mathrm{EC}$ is reported from the Ussangoda soil, potentially due to the deposition of salt spray from the sea. The organic carbon content of the soil ranges from 1.09 to $2.58 \%$. The highest organic carbon percentage is reported from Yudhaganawa soil which is adjacent to a forested habitat. Furthermore, a considerable color difference was identified among the soil samples collected from the four localities (Fig. 3).
Depending on soil $\mathrm{pH}$, mineral surfaces can bear net negative, positive, or no charge. The $\mathrm{pH}$ where the net electrical charge is zero is the zero point of charge $\left(\mathrm{pH}_{\mathrm{ZPC}}\right)$, and it is a parameter used to describe variable-charge surfaces (Morais et al. 1976; Parks and de Bruyn 1961). Titrations performed at three ionic strengths provide the $\mathrm{pH}_{\mathrm{ZPC}}$ at $\mathrm{pH} 8.57,8.90,8.30$, and 8.01 for Ussangoda, Yudhaganawa, Ginigalpelessa, and Indikolapelessa, respectively (Table 1). As observed, it is evident that the surface hydroxyl functional groups in the serpentine soils behave amphoterically.
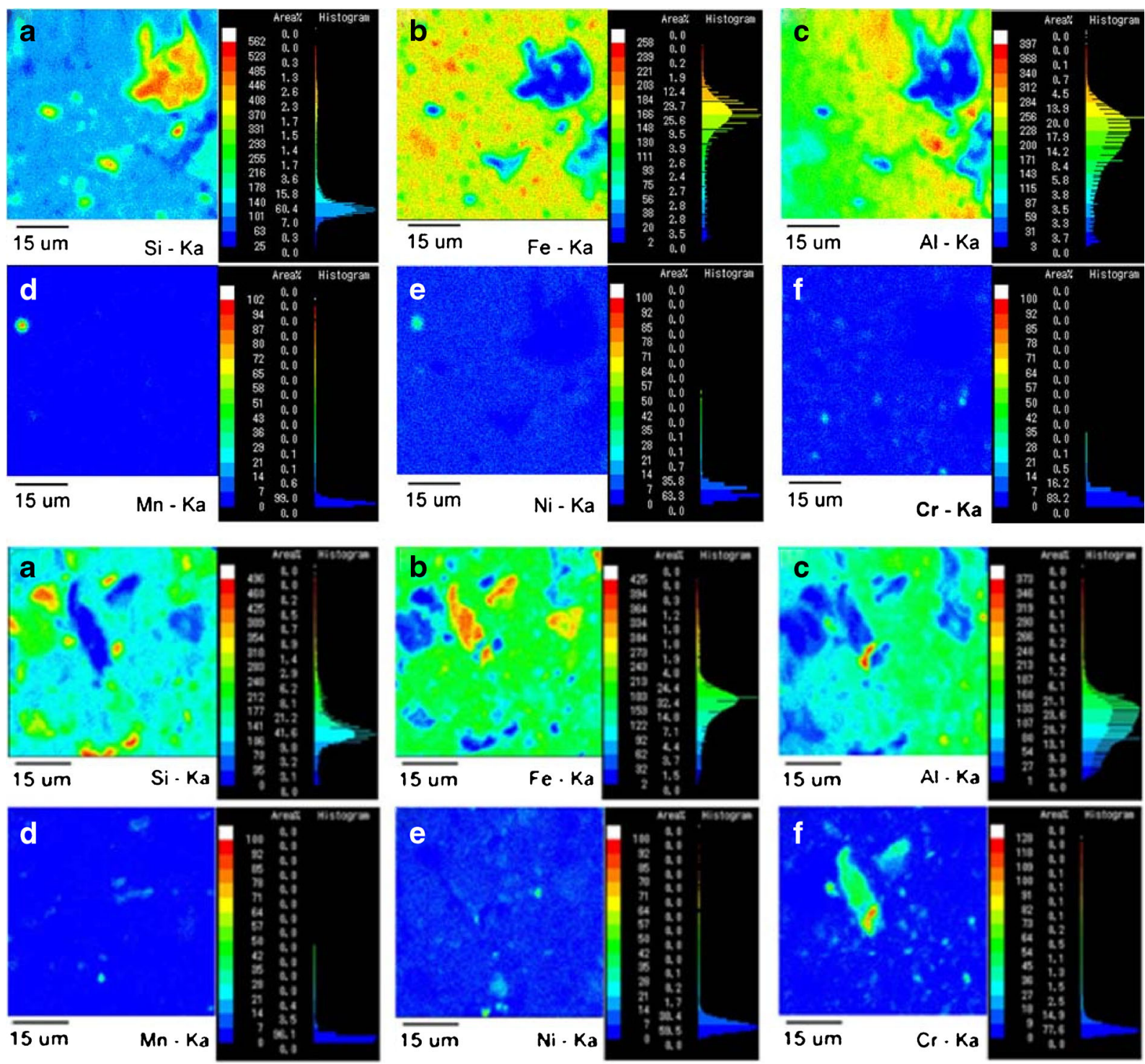

Fig. 5 EPMA analysis of Ussangoda (upper) and Yudhaganawa (lower) serpentine soil for different elements: a Si, b Fe, c Al, d Mn, e Ni, and $\mathbf{f} \mathrm{Cr}$ 
$\mathrm{XRD}$ analysis is important for revealing the mineralogical composition of the soils as shown for the Ussangoda soil in Fig. 4. Our results also document XRD patterns similar to those reported from previous studies (Sucik et al. 2008; Camachoa and Armientac 2000). Analyses reveal that antigorite $\left((\mathrm{Mg}, \mathrm{Fe})_{3} \mathrm{Si}_{2} \mathrm{O}_{5}\right.$ $\left.(\mathrm{OH})_{4}\right)$ is often the dominant mineral present with minor amounts of chrysotile $\left(\mathrm{Mg}_{3}\left(\mathrm{Si}_{2} \mathrm{O}_{5}\right)(\mathrm{OH})_{4}\right)$, magnetite $\left(\mathrm{Fe}_{3} \mathrm{O}_{4}\right)$, spinels, and clays.

Soil chemical properties $(\mathrm{pH}$, electrical conductivity, organic matter, cation exchange capacity), surface titrations, EPMA, and SEM analysis of serpentine soils collected from different localities in Sri Lanka are not significantly different. $\mathrm{pH}$ of the soil is near neutral and the range of EC is indicative of relatively few dissolved salts and/or major dissolved inorganic solutes (Oze et al. 2004b). These data corroborate with serpentine soil data reported from CA, USA (Oze et al. 2004b). However, serpentine soils from the coastal Ussangoda site show high EC and CEC compared to the other inland serpentine soils, which may be due to the deposition of salts from sea spray.

XRF analysis and total metal concentrations of the soils are reported in Table 2. The elemental composition of serpentine soils was obtained using XRF and total digestion techniques. Both techniques are complimentary; major elements in metal oxides were determined by XRF spectrophotometry and in elemental form via total digestion. The XRF results (Table 2) show that the soils consist of $\mathrm{Fe}-\mathrm{Cr}-\mathrm{Ni}$-rich aluminosilicates. Additionally, $\mathrm{Mn}$ is high in the samples, especially in the Yudhaganawa $\left(2,609 \mathrm{mg} \mathrm{kg}^{-1}\right)$ and Ginigalpelessa

Table 3 Different phases of Ni, Mn, and $\mathrm{Cr}$ from sequential extraction data for serpentine soils from four locations

\begin{tabular}{|c|c|c|c|c|c|c|c|}
\hline \multirow[t]{2}{*}{ Location } & \multirow[t]{2}{*}{ Fractions } & \multicolumn{3}{|c|}{ Amount released $\left(\mathrm{mg} \mathrm{kg}^{-1}\right)$} & \multicolumn{3}{|c|}{$\%$ of total ${ }^{\mathrm{a}}$} \\
\hline & & $\mathrm{Ni}$ & $\mathrm{Mn}$ & $\mathrm{Cr}$ & $\mathrm{Ni}$ & $\mathrm{Mn}$ & $\mathrm{Cr}$ \\
\hline \multirow[t]{6}{*}{ Ussangoda } & Exchangeable & $257.8(9.2)$ & $49.4(4.0)$ & $0.7(0.2)$ & 4.0 & 4.4 & $<0.1$ \\
\hline & Carbonates & $47.2(8.8)$ & $10.2(3.4)$ & $0.4(0.3)$ & 0.7 & 0.9 & $<0.1$ \\
\hline & Fe and Mn oxides & $464.4(6.6)$ & $420.7(1.2)$ & $90.6(1.8)$ & 7.2 & 37.5 & 0.4 \\
\hline & Organic matter & $268.8(7.9)$ & $62.24(6.8)$ & $508.5(1.9)$ & 4.2 & 5.6 & 4.6 \\
\hline & Residual/silicate & 4,697 (9.8) & $351.5(7.8)$ & $8,567.9(14.5)$ & 72.7 & 31.4 & 83.1 \\
\hline & Sum of (a) to (e) & 5,735 & 894 & $9,168.1$ & & & \\
\hline \multirow[t]{6}{*}{ Indikolapelessa } & Exchangeable & $16.4(1.7)$ & $14.7(0.7)$ & $3.9(0.8)$ & 0.3 & 0.7 & $<0.1$ \\
\hline & Carbonates & $27.9(1.2)$ & $25.1(0.3)$ & $3.8(1.1)$ & 0.5 & 1.1 & $<0.1$ \\
\hline & Fe and Mn oxides & $870.6(20.5)$ & $1,324.2(47.8)$ & $30.7(10.4)$ & 15.5 & 59.5 & 0.5 \\
\hline & Organic matter & $313.9(1.6)$ & $251.5(3.2)$ & $40.4(4.0)$ & 5.6 & 11.3 & 0.6 \\
\hline & Residual/silicate & $3,913.8(14.2)$ & $29.3(3.6)$ & $5,385.0(47.7)$ & 69.6 & 1.32 & 79.9 \\
\hline & Sum of (a) to (e) & $5,142.7$ & $1,724.9$ & $5,463.8$ & & & \\
\hline \multirow[t]{6}{*}{ Ginigalpelessa } & Exchangeable & $37.3(1.4)$ & $7.5(2.2)$ & $1.2(0.2)$ & 0.7 & 0.6 & $<0.1$ \\
\hline & Carbonates & $47.4(0.6)$ & $15.9(1.0)$ & $1.1(0.2)$ & 0.9 & 1.2 & $<0.1$ \\
\hline & $\mathrm{Fe}$ and $\mathrm{Mn}$ oxides & $1,115.3(87.1)$ & $1,062.3(84.3)$ & $28.4(9.3)$ & 22.6 & 79.2 & 0.3 \\
\hline & Organic matter & $407.64(18.1)$ & $207.9(0.2)$ & $50.7(6.8)$ & 8.3 & 15.5 & 0.5 \\
\hline & Residual/silicate & $3,167.3(62.8)$ & $42.5(0.3)$ & $7,620.5(29.6)$ & 64.2 & 3.2 & 76.5 \\
\hline & Sum of (a) to (e) & $4,774.9$ & $1,336.1$ & $7,701.9$ & & & \\
\hline \multirow[t]{6}{*}{ Yudhaganawa } & Exchangeable & $134.1(4.2)$ & $9.7(4.1)$ & $3.2(0.2)$ & 2.1 & 0.4 & $<0.1$ \\
\hline & Carbonates & $67.9(1.6)$ & $21.7(3.6)$ & $8.2(3.6)$ & 1.1 & 1.0 & $<0.1$ \\
\hline & Fe and Mn oxides & $642.6(9.5)$ & $1,467.1(3.6)$ & $76.7(10.4)$ & 10.4 & 64.8 & 0.5 \\
\hline & Organic matter & $446.4(21.4)$ & $390.9(21.3)$ & $693.1(13.6)$ & 6.9 & 17.2 & 4.6 \\
\hline & Residual/silicate & $5,003.5(8.6)$ & $50.2(16.4)$ & $8,448.8(100.9)$ & 78.2 & 2.2 & 56.7 \\
\hline & Sum of (a) to (e) & $6,294.6$ & $1,839.6$ & $9,230.0$ & & & \\
\hline
\end{tabular}

Values reported are averages for five determinations, and the value in parentheses is the standard deviation for that element and method

${ }^{\text {a }}$ Total Ni, Mn, and Cr values via XRF are reported in Table 2 
$\left(2,224 \mathrm{mg} \mathrm{kg}^{-1}\right)$ soils. Nickel is the highest in Ussangoda soils $\left(6,459 \mathrm{mg} \mathrm{kg}^{-1}\right)$, while $\mathrm{Cr}$ is higher in Yudhaganawa $\left(>10,000 \mathrm{mg} \mathrm{kg}^{-1}\right)$ soil compared to soils from the other localities.

EPMA analysis maps show the distribution of $\mathrm{Ni}$, $\mathrm{Mn}$, and $\mathrm{Cr}$ with $\mathrm{Al}, \mathrm{Fe}$, and $\mathrm{Si}$ phases (Fig. 5). Overall, these maps reveal that $\mathrm{Ni}, \mathrm{Mn}$, and $\mathrm{Cr}$ are not homogeneously distributed in the soil, suggesting that the metals are bound in specific mineral phases. EPMA results of different serpentine soils corroborate with data from XRF values. Cursory observations demonstrate that the $\mathrm{Cr}$ distribution is related to the $\mathrm{Fe}$ and $\mathrm{Al}$ phases of the serpentine soils as shown in Fig. 5, whereas the Ni distribution is consistent with the Si phases. Even though antigorite is a dominant mineral in the soil as shown by XRD, it has a relatively low surface area compared to clays or organic matter and, therefore, would contribute/release less metal compared to a high surface area/highly reactive mineral/phase in the soil. This is a major critique of chemical extractions. In chemical extractions, surface area and reactivity of a given fraction/phase is a major factor influencing metal release; however, these extractions do provide a means to begin differentiating the abundance and release of metals in a very complex medium (i.e., soil).

\section{Metal-bound phases}

Sequential extraction results for the serpentine soils are presented in Table 3. Mean values with standard deviations are reported. Nickel, $\mathrm{Mn}$, and $\mathrm{Cr}$ concentrations for each chemical extraction step are shown (in milligrams per kilogram) as well as the percentage (in percent) extracted from the total value (Fig. 6). Manganese is equally bound in the $\mathrm{Fe}-\mathrm{Mn}$ oxide fraction (420.7 $\left.\mathrm{mg} \mathrm{kg}^{-1}, 37 \%\right)$ as in the residual fraction ( $351 \mathrm{mg} \mathrm{kg}^{-1}, 31 \%$ ). The residual fraction is associated with silicates as well as with other primary oxides such as spinels. Nickel is dominantly bound in the residual fraction (4,697 $\left.\mathrm{mg} \mathrm{kg}^{-1}, 72 \%\right)$, and $\mathrm{Cr}$ predominates in the residual fraction and is organic matter bound (8,567 $\mathrm{mg} \mathrm{kg}^{-1}, 83 \%$ and $508 \mathrm{mg} \mathrm{kg}^{-1}, 4.6 \%$, respectively). The order of the individual geochemical fractions where $\mathrm{Cr}, \mathrm{Ni}$, and $\mathrm{Mn}$ are bound from the greatest to least are: (1) Cr: residual $>$ organic matter bound $>\mathrm{Fe}$ and Mn bound $>$ exchangeable $>$ carbonate bound, (2) $\mathrm{Ni}$ : residual $>\mathrm{Fe}$ and $\mathrm{Mn}$ oxide bound $>$ organic matter bound $>$ exchangeable $>$ carbonate bound, and (3) Mn:
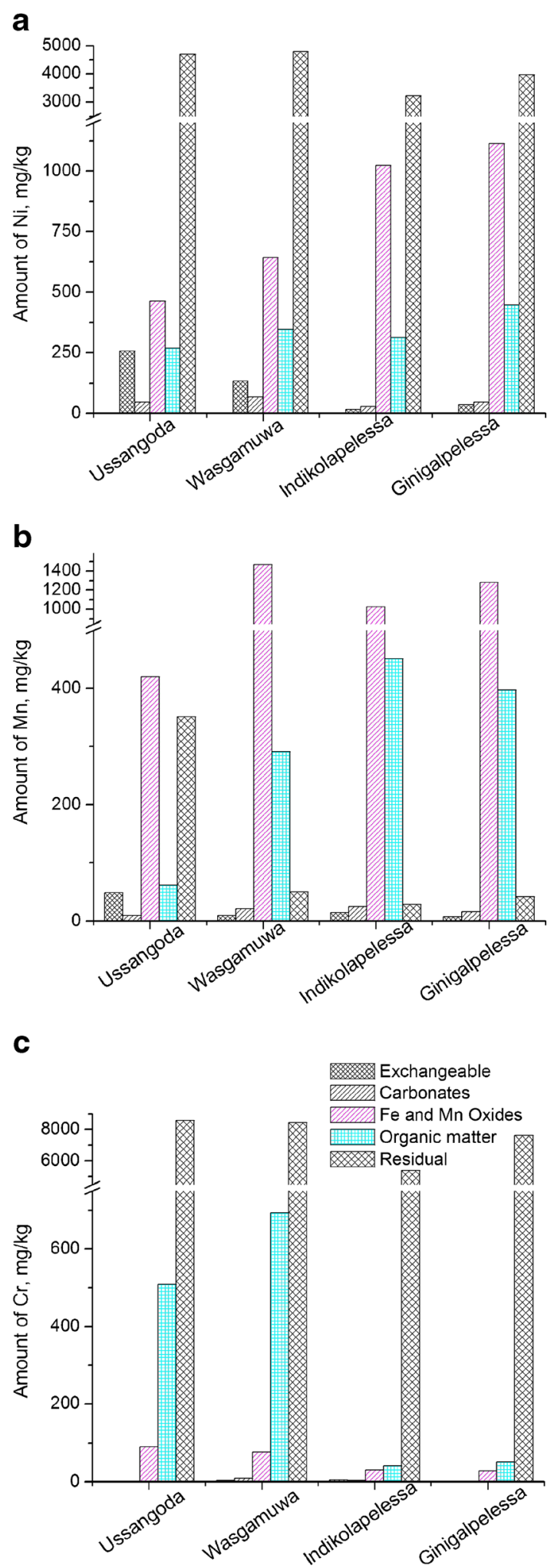

Fig. 6 Fractionation and availability of metals in different phases of serpentine soil from different localities: a Ni, b Mn, and $\mathbf{c} \mathrm{Cr}$ 
Fe and Mn oxide bound $>$ residual $>$ organic matter bound $>$ exchangeable $>$ carbonate bound.

Heavy metals are present as exchangeable or associated with organic matter, carbonates, Fe-Mn oxides, and sulfides in the soil matrix fractions. Chemical extractions are utilized to assess the geochemical partitioning of metals as well as to evaluate metal mobility and bioavailability in soils and sediments. However, changes in soil $\mathrm{pH}$, ionic strength, and other environmental factors may affect metal mobilization in soil environments, especially with respect to time and land use. By coupling single and sequential extractions with chemical kinetic interpretations, it is possible to gain better insight with respect to where and how $\mathrm{Ni}, \mathrm{Mn}$, and $\mathrm{Cr}$ are bound. More importantly, the fate and behavior of $\mathrm{Ni}, \mathrm{Mn}$, and $\mathrm{Cr}$ as they are mobilized and/or affected by critical zone processes can also be interpreted for a wide variety of potential chemical changes, including those related to the addition of fertilizers and changes in rainwater chemistry (Rajapaksha et al. 2012).

Sequential extraction experiments provide information on association of species, enabling the differentiation between "elemental pools" based on how they are attached and/or what minerals they are associated with, including carbonates, (oxy)hydroxides, or silicates. Even though these metals are dominantly bound in relatively unavailable forms, changes in the critical zone such as soil acidity, microbial activity, availability of chelating materials, and redox conditions can enhance the mobility, providing a continually changing flux into the environment. It is important to note that bioavailable, exchangeable, and carbonate-bound fractions may have less overall $\mathrm{Ni}, \mathrm{Mn}$, and $\mathrm{Cr}$; however, these fractions potentially offer a more labile source in soil environments.

Several differences are present among serpentine soils from different localities. The exchangeable fraction of Ni was higher in Ussangoda and Yudhaganawa soils (Table 3) compared to Indikolapelessa and Ginigalpelessa soils, which may be due to the slightly higher $\mathrm{pH}$ and lower organic matter content at the latter two sites. In the case of $\mathrm{Mn}$, all soils except those from Ussangoda show the second highest $\mathrm{Mn}$ in the organic matter-bound fraction and third in the residual fraction. This difference may be due to the changes in mineralogy. In soils derived from serpentinite (Becquer et al. 2003; Gasser and Dahlgren 1994; Oze et al. 2004a), most Cr is bound in the structure of primary minerals such as $\mathrm{Cr}$ rich spinels (i.e., chromite) and Cr-substituted Fe oxides. The results support that antigorite (i.e., the dominant mineral identified in these serpentine soils via XRD) could be a contributor to $\mathrm{Ni}$ and $\mathrm{Mn}$ release, whereas the Cr-spinel (chromite/Cr-muscovite) is a potential major source of $\mathrm{Cr}$ (Rajapaksha et al. 2012). A substantial proportion of $\mathrm{Cr}$ was linked with organic matter, and the high proportion substantiates the high affinity of $\mathrm{Cr}$ for organic matter (Kabata-Pendias and Pendias 2001).

\section{Single extractions}

The DTPA treatment extracted $323 \mathrm{mg} \mathrm{kg}^{-1}$ (5.0\%) of $\mathrm{Ni}$ and $76.3 \mathrm{mg} \mathrm{kg}^{-1}$ (6.8\%) of Mn for the Ussangoda soil. Nickel and $\mathrm{Mn}$ extractions with $0.01 \mathrm{M} \mathrm{CaCl}_{2}$ are lower than that of DTPA in the slightly acidic serpentine soils and are $167.6(2.6 \%)$ for $\mathrm{Ni}$ and 45.51 (4.1\%) $\mathrm{mg} \mathrm{kg}^{-1}$ for Mn (Table 4). Similarly, $\mathrm{NaNO}_{3}$ and distilled water (at $\mathrm{pH}$ 6.5) extractable $\mathrm{Ni}$ and $\mathrm{Mn}$ are comparatively higher in the Ussangoda soils (Table 5).

The DTPA and $\mathrm{CaCl}_{2}$ extraction methods provide a proxy for evaluating plant bioavailability of $\mathrm{Ni}$ and $\mathrm{Mn}$ in soils and soil solutions (Kashem et al. 2007; Peijnenburg et al. 2007). Since DTPA forms soluble

Table 4 Labile ions as bioavailable and exchangeable for $\mathrm{Ni}, \mathrm{Mn}$, and $\mathrm{Cr}$ in serpentine soils from different localities

\begin{tabular}{|c|c|c|c|c|c|c|}
\hline \multirow[t]{2}{*}{ Locations } & \multicolumn{2}{|c|}{ Amount Ni released $\left(\mathrm{mg} \mathrm{kg}^{-1}\right)$} & \multicolumn{2}{|c|}{ Amount Mn released $\left(\mathrm{mg} \mathrm{kg}^{-1}\right)$} & \multicolumn{2}{|c|}{ Amount $\mathrm{Cr}$ released $\left(\mathrm{mg} \mathrm{kg}^{-1}\right)$} \\
\hline & $\begin{array}{l}0.01 \mathrm{M} \mathrm{CaCl}_{2} \\
\text { extractable }\end{array}$ & $\begin{array}{l}0.005 \text { M DTPA } \\
\text { extractable }\end{array}$ & $\begin{array}{l}0.01 \mathrm{M} \mathrm{CaCl}_{2} \\
\text { extractable }\end{array}$ & $\begin{array}{l}0.005 \text { M DTPA } \\
\text { extractable }\end{array}$ & $\begin{array}{l}0.01 \mathrm{M} \mathrm{CaCl}_{2} \\
\text { extractable }\end{array}$ & $\begin{array}{l}0.005 \text { M DTPA } \\
\text { extractable }\end{array}$ \\
\hline Ussangoda & $167.6(6.4)$ & $323(2.3)$ & $45.5(3.0)$ & $76.3(3.1)$ & ND & $0.35(0.1)$ \\
\hline Indikolapelessa & $19.8(2.9)$ & $33.6(3.9)$ & $17.9(1.0)$ & $26.7(1.7)$ & ND & $0.07(0.01)$ \\
\hline Ginigalpelessa & $34.2(1.1)$ & $99.1(4.2)$ & $7.19(0.8)$ & $11.0(2.9)$ & ND & ND \\
\hline Yudhaganawa & $127(5.1)$ & $301(7.2)$ & $18.3(3.1)$ & $31.3(0.8)$ & ND & $0.18(0.01)$ \\
\hline
\end{tabular}

Values reported are averages for five determinations, and the value in parentheses is the standard deviation for that element and method ND not detectable 
complexes with metals, thereby reducing their activity in the soil solutions, $\mathrm{Ni}$ and $\mathrm{Mn}$ ions may be desorbed from the soil and enter into the solution. Extractions with $\mathrm{CaCl}_{2}$ are commonly used to assess plant bioavailability, especially in neutral or weakly alkaline soils. High concentrations of $\mathrm{Ni}$ and $\mathrm{Mn}$ release ( $>19$ and $>7 \mathrm{mg} \mathrm{kg}^{-1}$, respectively) are present from all serpentine soil localities. The concentrations recorded from $\mathrm{CaCl}_{2}$ extractions were about $\sim 50 \%$ lower than the DTPA extractable concentrations (Table 4). Some studies have shown that salt solutions do not accurately reflect the plant available metals, especially in the case of non-calcareous soils, whereas DTPA or hydroxylamine methods are more predictive (Gupta and Aten 1993; Aydinalp and Katkat 2004). Similar to the other extraction results, Ussangoda and Yudhaganawa soils demonstrate higher leaching capacities of Ni, Mn, and Cr than the other two soils (Table 4). This directly relates to the total metal concentration differences among soils from different localities.

Although this study did not reveal substantial differences in soil $\mathrm{pH}$ among the four sites, our $\mathrm{pH}$ results (Table 1) parallel the trend seen in previous research, documenting the lowest rhizospheric $\mathrm{pH}$ for soils at the Ussangoda site (4.3-4.9; Rajakaruna and Bohm 2002) followed by the Yudhaganawa site (5.05-5.65; Rajakaruna and Bohm 2002). The lower $\mathrm{pH}$ at these two sites may also contribute to the greater leaching capacity documented. It is widely known that the solubility and mobility of $\mathrm{Ni}$ in soils increases as $\mathrm{pH}$ decreases, at least within the $\mathrm{pH}$ range of physiological significance (McGrath 1995). By using ion-exchange kinetics, Echevarria et al. (2006) documented $\mathrm{pH}$ as the main factor influencing $\mathrm{Ni}$ availability in a wide range of natural soils, and Tye et al. (2004) have shown that $\mathrm{pH}$ is also a major influence on Ni activity in a range of contaminated soils. The more labile Ni obviously contributes to greater opportunity for plant uptake (Kukier et al. 2004) and may have contributed to the highest tissue Ni content so far observed, including levels of hyperaccumulation, for species growing at the Ussangoda site (Rajakaruna and Bohm 2002; Weerasinghe and Iqbal 2011). Chromium was not detected (detection limit was $0.001 \mathrm{mg} \mathrm{kg}^{-1}$ ) from $\mathrm{CaCl}_{2}$ extractions from any serpentine soil, although DTPA shows bioavailable concentrations for the soils from Ussangoda, Indikolapelessa, and Yudhaganawa (Table 4). Low bioavailable Cr may be due to the higher affinity of $\mathrm{Cr}$ to adsorb to clay surfaces and humic matter (Fendorf 1995). 
Water and ionic strength extractable fraction of metals may be more representative of soils being exposed to sea spray or what is available for water pollution and plant uptake, including to those species shown to hyperaccumulate $\mathrm{Ni}$ at the Ussangoda site (Rajakaruna and Bohm 2002; Weerasinghe and Iqbal 2011). Distilled water and $\mathrm{NaNO}_{3}$ extractable data show high release of $\mathrm{Ni}$ than $\mathrm{Mn}$ or $\mathrm{Cr}$ (Table 5). The highest distilled water extractable $\mathrm{Ni}$ and $\mathrm{Mn}$ was observed from Ussangoda soil, and it shows a reduction in the sequence of Yudhaganawa, Indikolapelessa, and Ginigalpelessa. This sequence may be related with the total amount of Ni present in the soil as observed from the XRF and total digestion data. However, the behavior of $\mathrm{Mn}$ release with distilled water and $\mathrm{NaNO}_{3}$ is different from the total $\mathrm{Mn}$ present; rather, it is related to total $\mathrm{Fe}$ in the soil. This may be related to the Fe- and Mn-bound fraction of soils. However, the Mn release sequence is similar to that of $\mathrm{Ni}$. In the case of $\mathrm{NaNO}_{3}$ extractable metal ions, with the decrease of ionic strength, the metal ion release also shows a decline. Dissolution rates are enhanced by increasing ionic strength due to surface protonation displacing ions from surface sites (Mogollón et al. 2000). Chromium does not show any release in soils except at Yudhaganawa with $\mathrm{NaNO}_{3}$, although the total concentrations reported were higher than Ni and Mn. Since Cr (III) is highly stable, strong complex formation with humic matter may have stopped it from dissolving (Fendorf 1995).

\section{Remarks}

Our study demonstrates that the weathering of ultramafic rocks and serpentinites in Sri Lanka produces soils containing high concentrations of $\mathrm{Cr}, \mathrm{Ni}, \mathrm{Co}$, and $\mathrm{Mn}$ (i.e., similar to other serpentine soils) and that these metals can potentially be released to local water bodies. Our chemical characterizations show that the soils from Yudhaganawa site record the highest $\mathrm{Cr}$ and $\mathrm{Mn}$ concentrations, whereas Ussangoda soils show the highest concentration of $\mathrm{Ni}$. The greater availability of $\mathrm{Ni}$ may explain why this is the only site where high levels of plant tissue $\mathrm{Ni}$, including levels considered to be in the range of hyperaccumulation, were observed in plants tested from the four serpentine localities by Rajakaruna and Bohm (2002). Our study points to the importance of conducting a variety of extractions, ranging from single to sequential, in order to better assess bioavailable concentrations, including how labile elements can be released over a range of geochemical conditions.

Acknowledgements International Foundation for Science (Sweden) and Organization for the Prohibition of Chemical Weapons, The Hague, are kindly acknowledged for their funding (grant number W/5068-1). Authors thank Dr. J.C. Bailey at the Institute for Geography and Geology, University of Copenhagen and Dr. Steen Christensen and colleagues at the Department of Earth Sciences, University of Aarhus, Denmark for providing XRF results and Prof. Y. S. Ok at the Department of Biological Environment at Kangwon National University, South Korea for EPMA analysis.

\section{References}

Alexander, E. B. (2004). Serpentine soil redness, differences among peridotite and serpentinite materials, Klamath Mountains, California. International Geology Review, 46(8), 754-764.

Alves, S., Trancoso, M. A., Gonçalves, M. d. L. S., \& Correia dos Santos, M. M. (2011). A nickel availability study in serpentinised areas of Portugal. Geoderma, 164(3-4), 155-163.

Amir, H., \& Pineau, R. (2003). Release of Ni and Co by microbial activity in New Caledonian ultramafic soils. Canadian Journal of Microbiology, 49(4), 288-293.

Armienta, M. A., Rodríguez, R., Ceniceros, N., Juárez, F., \& Cruz, O. (1996). Distribution, origin and fate of chromium in soils in Guanajuato, Mexico. Environmental Pollution, 91(3), 391-397.

Aydinalp, C., \& Katkat, A. V. (2004). The comparison of extraction methods for evaluating some heavy metals in polluted soils. Plant Soil Environment, 50(5), 212-217.

Becquer, T., Quantin, C., Sicot, M., \& Boudot, J. P. (2003). Chromium availability in ultramafic soils from New Caledonia. Science of the Total Environment, 301(1-3), 251-261.

Boyd, R. S., Kruckeberg, A. R., \& Rajakaruna, N. (2009). Biology of ultramafic rocks and soils: research goals for the future. Northeastern Naturalist, 16(5), 422-440.

Brooks, R. R. (1987). Serpentine and its vegetation: a multidisciplinary approach. Portland: Dioscorides.

Camachoa, J. R., \& Armientac, M. A. (2000). Natural chromium contamination of groundwater at Leo'n Valley, Mexico. Journal of Geochemical Exploration, 68, 167-181.

Castilho, P. D., \& Rix, I. (1993). Ammonium acetate extraction for soil heavy metal speciation; model aided soil test interpretation. International Journal of Environmental Analytical Chemistry, 51(1-4), 59-64.

Cheng, C.-. H., Jien, S.-. H., Iizuka, Y., Tsai, H., Chang, Y.-. H., \& Hseu, Z.-Y. (2011). Pedogenic chromium and nickel partitioning in serpentine soils along a toposequence. Soil Science Society of America Journal, 75(2), 659-668.

Coleman, R. G. (1977). Ophiolites: ancient oceanic lithosphere? Berlin: Springer. 
Coleman, R. G., \& Jove, C. (1992). Geological origin of serpentinites. In: A. J. M. Baker, J. Proctor, \& R. D. Reeves (Eds.), The vegetation of ultramafic (serpentine) soils. Proceedings of the First International Conference on Serpentine Ecology (pp. 1-17). Hampshire: Intercept.

Cooray, P. G. (1984). An introduction to the geology of Sri Lanka (Ceylon). Colombo: National Museums of Sri Lanka.

Dissanayaka, C. B. (1982). The geology and geochemistry of the Uda Walawe serpentinite. Sri Lanka. Journal National Science Council Sri Lanka, 10, 13-34.

Dissanayake, C. B., \& Van Riel, B. J. (1978). The petrology and geochemistry of a recently discovered nickeliferous serpentinite from Sri Lanka. Journal of the Geological Society of India, 19, 464-471.

Echevarria, G., Massoura, S. T., Sterckeman, T., Becquer, T., Schwartz, C., \& Morel, J. L. (2006). Assessment and control of the bioavailability of nickel in soils. Environmental Toxicology and Chemistry, 25(3), 643-651.

Fendorf, S. E. (1995). Surface reactions of chromium in soils and waters. Geoderma, 67(1-2), 55-71.

Gasser, U. G., \& Dahlgren, R. A. (1994). Solid-phase speciation and surface association of metals in serpentinitic soils. Soil Science and Plant Nutrition, 158, 409-420.

Gleyzes, C., Tellier, S., \& Astruc, M. (2002). Fractionation studies of trace elements in contaminated soils and sediments: a review of sequential extraction procedures. TrAC Trends in Analytical Chemistry, 21(6-7), 451-467.

Gough, L. P., Meadows, G. R., Jackson, L. L., \& Dudka, S. (1989). Biogeochemistry of highly serpentinized chromite rich ultramafic area, Tehma County, California. USGS Bulletin, 1901.

Gupta, S. K., \& Aten, C. (1993). Comparison and evaluation of extraction media and their suitability in a simple model to predict the biological relevance of heavy metal concentrations in contaminated soils. International Journal of Environmental Analytical Chemistry, 51(1-4), 25-46.

Harris, T., \& Rajakaruna, N. (2009). Adiantum viridimontanum, Aspidotis densa, Minuartia marcescens, and Symphyotrichum rhiannon: additional serpentine endemics from Eastern North America. Northeastern Naturalist, 16(sp5), 111-120.

Harrison, S., \& Kruckeberg, A. R. (2008). Garden on the rocks. Natural History, 117, 40-44.

Harrison, S., \& Rajakaruna, N. (2011). Serpentine: the evolution and ecology of a model system. Berkeley: University of California Press.

Houba, V. J. G., Lexmond, T. M., Novozamsky, I., \& Lee, J. J. (1996). State of the art and future developments in soil analysis for bioavailability assessment. Science of the Total Environment, 178, 21-28.

Kabata-Pendias, A., \& Pendias, H. (2001). Trace elements in soils and plants (3rd ed.). Boca Raton: CRC.

Kashem, M. A., Singh, B. R., Kondo, T., Imamul Huq, S. M., \& Kawai, S. (2007). Comparison of extractability of $\mathrm{Cd}, \mathrm{Cu}, \mathrm{Pb}$ and $\mathrm{Zn}$ with sequential extraction in contaminated and noncontaminated soils. International Journal Environmental Science Technology, 4(2), 169-176.

Kukier, U., Peters, C. A., Chaney, R. L., Angle, J. S., \& Roseberg, R. J. (2004). The effect of $\mathrm{pH}$ on metal accumulation in two alyssum species. Journal of Environmental Quality, 33(6), 2090-2102.
Langmuir, D. (1997). Aqueous environmental geochemistry. Englewood Cliffs: Prentice Hall.

Lindsay, W. L., \& Norvell, W. A. (1978). Development of a DTPA soil test for zinc, iron, manganese, and copper. Soil Science Society of America Journal, 42(3), 421-428.

McGrath, S. P. (1995). Chromium and nickel. In B. J. Alloway (Ed.), Heavy metals in soils (pp. 152-174). London: Blackie Academic and Professional.

Mogollón, J. L., Pérez-Diaz, A., \& Lo Monaco, S. (2000). The effects of ion identity and ionic strength on the dissolution rate of a gibbsitic bauxite. Geochimica et Cosmochimica Acta, 64(5), 781-795.

Morais, F. I., Page, A. L., \& Lund, L. J. (1976). The effect of pH, salt concentration, and nature of electrolytes on the charge characteristics of Brazilian tropical soils. Soil Science Society of America Journal, 40, 521-527.

Munasinghe, T., \& Dissanayake, C. B. (1980). Is the Highlandeastern Vijayan boundary in Sri Lanka a possible mineralized belt? Economic Geology, 75(5), 775-777.

Myers, N., Mittermeier, R. A., Mittermeier, C. G., da Fonseca, G. A. B., \& Kent, J. (2000). Biodiversity hotspots for conservation priorities. Nature, 403(6772), 853-858.

O'Hanley, D. S. (1996). Serpentinites: records of tectonic and petrological history. Oxford monographs on geology and geophysics (34th ed.). New York: Oxford University Press.

Oze, C. (2003). Chromium geochemistry of serpentinites and serpentine soils. Stanford: Stanford University.

Oze, C., Fendorf, S., Bird, D. K., \& Coleman, R. G. (2004a). Chromium geochemistry in serpentinized ultramafic rocks and serpentine soils from the Franciscan complex of California. American Journal Science, 304, 67-101.

Oze, C., Fendorf, S., Bird, D. K., \& Coleman, R. G. (2004b). Chromium geochemistry of serpentine soils. International Geology Review, 46, 97-126.

Oze, C., Skinner, C., Schroth, A., \& Coleman, R. G. (2008). Growing up green on serpentine soils: biogeochemistry of serpentine vegetation in the Central Coast Range of California. Applied Geochemistry, 23, 3391-3403.

Parks, G. A., \& de Bruyn, P. L. (1961). The zero point of charge of oxides. The Journal of Physical Chemistry, 66, 967-973.

Peijnenburg, W. J. G., Zablotskaja, M., \& Vijver, M. G. (2007). Monitoring metals in terrestrial environments within a bioavailability framework and a focus on soil extraction. Ecotoxicology and Environmental Safety, 67, 163-179.

Proctor, J., \& Baker, A. J. M. (1994). The importance of nickel for plant growth in ultramafic (serpentine) soils. In S. M. Ross (Ed.), Toxic metals in soil-plant systems (pp. 417-432). Chichester: Wiley.

Rajakaruna, N., \& Baker, J. M. (2004). Serpentine: a model habitat for botanical research in Sri Lanka. Ceylon Journal of Science (Biological Sciences), 32, 1-19.

Rajakaruna, N., \& Bohm, B. A. (2002). Serpentine and its vegetation: a preliminary study from Sri Lanka. Journal of Applied Botany, 76, 20-28.

Rajakaruna, N., Harris, C. S., \& Towers, G. H. N. (2002). Antimicrobial activity of plants collected from serpentine outcrops in Sri Lanka. Pharmaceutical Biology, 40(3), 235244.

Rajakaruna, N., Harris, T. B., \& Alexander, E. B. (2009). Serpentine geoecology of Eastern North America: a review. Rhodora, 111(945), 21-108. 
Rajapaksha, A. U., Vithanage, M., Oze, C., Bandara, W. M. A. T., \& Weerasooriya, R. (2012). Nickel and manganese release in serpentine soil from the Ussangoda ultramafic complex, Sri Lanka. Geoderma, 189-190, 1-9.

Ranasinghe, N. S. (1987). Serpentinites associated with the precambrian of Sri Lanka. Geological Society of Sri Lanka special publication no. 3. Colombo: Geological Survey Department.

Senevirathne, A. S., Nandadasa, H. G., Fernando, W. S., Sanjeevani, H. H. V. M., \& Rajapakshe, R. L. H. R. (2000). The serpentine vegetation of Ussangoda (Hambantota District) and nickel accumulating plant species. Paper presented at the Proceedings of the Sixth Annual Forestry and Environmental Symposium, Kandy, Sri Lanka, 29-30 December.

Stumm, W., \& Morgan, J. J. (1996). Aquatic chemistry. New York: Wiley Inter-Science.

Sucik, G., Hrsak, D., Fedorockova, A., \& Lazic, L. (2008). The preliminary characterization of serpentinite from Ljeskovac locality in Croatia. Acta Metallurgica Slovaca, 14, 275-280.
Sun, Y.-c., Chi, P.-h., \& Shiue, M.-y. (2001). Comparison of different digestion methods for total decomposition of siliceous and organic environmental samples. Analytical Sciences, 17(12), 1395-1399.

Tessier, A., Campbell, P. G. C., \& Bisson, M. (1979). Sequential extraction procedure for the speciation of particulate trace metals. Analytical Chemistry, 51(7), 844-851.

Tye, A. M., Young, S., Crout, N. M. J., Zhang, H., Preston, S., Zhao, F. J., et al. (2004). Speciation and solubility of $\mathrm{Cu}, \mathrm{Ni}$ and $\mathrm{Pb}$ in contaminated soils. European Journal of Soil Science, 55(3), 579-590.

Van der Ent, A., Baker, A. M., Reeves, R., Pollard, A. J., \& Schat, H. (2013). Hyperaccumulators of metal and metalloid trace elements: facts and fiction. Plant and Soil, 362(1-2), 319334.

Weerasinghe, H. A. S., \& Iqbal, M. C. M. (2011). Plant diversity and soil characteristics of the Ussangoda serpentine site. Journal National Science Foundation Sri Lanka, 39(4), 355-363. 